\title{
ANALYSIS OF THE EXPRESSION OF FAS/CD95 AND HSP70 IN LOW AND HIGH GRADE UROTHELIAL CELL CARCINOMA OF THE BLADDER
}

\author{
Heryanto, Etty Hary Kusumastuti, Anny Setijo Rahaju \\ Department of Anatomic Pathology, Faculty of Medicine, Universitas Airlangga, Dr. Soetomo Hospital, Surabaya
}

\begin{abstract}
ABSTRAK
Urothelial cell carcinoma, disebut juga transitional cell carcinoma pada vesica urinaria, merupakan keganasan yang sering terjadi pada saluran kencing. Salah satu prognosis dari penyakit ini sangat tergantung pada grading histologi dari tumor pada saat diagnosis. CD95 memiliki peran dalam proses apoptosis dan HSP70 memiliki peran sebagai antiapoptosis. Penelitian ini bertujuan untuk mengetahui ekspresi CD95 dan HSP70 pada berbagai grading pada karsinoma sel urotelial di vesika urinaria. Penelitian observasional dilakukan pada blok paraffin dari sediaan urothelial cell carcinoma yang tersimpan di Laboratorium Patologi Anatomi RSUD Dr. Sutomo, Surabaya pada bulan Januari 2011-Desember 2016 secara acak dan dengan total sampling. Kemudian, dilakukan pengecatan immunohistokimia dengan menggunakan antibodi CD95 dan HSP70. Ekspresi CD95 dan HSP70 dinilai secara semikuantitatif dan dianalisis dengan menggunakan uji statistik Mann-Whitney test dan Spearman test. Hasil penelitian ini menunjukkan perbedaan ekspresi pada CD95 dan HSP70 pada kelompok karsinoma sel urotelial derajat tinggi dan derajat rendah. Namun, tidak ada hubungan yang bermakna antara CD95 dan HSP70 pada karsinoma sel urotelial buli. Sebagai simpulan, Fas/CD95 dan HSP70 dapat bermanfaat sebagai marker untuk penegakkan diagnosis, terutama dalam penentuan derajat diferensiasi. (FMI 2017;53:247-251)
\end{abstract}

Kata kunci: CD95; HSP70; karsinoma sel urotelial

\begin{abstract}
Urothelial Cell Carcinoma (UCC), also called transitional cell carcinoma of the bladder, is the most common malignancy in urinary tract. The prognosis of this disease is highly dependent on the histological grading at diagnosis. Fas/CD95 has a role in apoptotic process, whereas HSP70 has an antiapoptotic role. This study aimed to analyze the expression of Fas/CD95 and HSP70 in low grade and high grade urothelial cell carcinoma in the bladder. This was an analytic observational study with cross sectional approach. Population and sample were paraffin blocks of urothelial cell carcinoma in the Laboratory of Anatomic Pathology, Dr. Soetomo Hospital, Surabaya in the period of January 2011-December 2016. Each grading of urothelial cell carcinoma was randomly sampled. Immunohistochemystry with Fas/CD95 and HSP70 were performed. Expression of Fas/CD95 and HSP70 were assessed semiquantitatively. Expression of Fas/CD95 and HSP70 were analyzed using Mann-Whitney test and Spearman test. The results showed there was significant different in expression of Fas/CD95 and HSP70 in low and high grades in urothelial cell carcinoma. There was no significant correlation between the expression of Fas/CD95 and HSP70 in urothelial cell carcinoma. As a conclusion, the role of CD95 and HSP70 expression can be useful as marker for the diagnosis, especially in the determination of the grade of differentiation. (FMI 2017;53:247-251)
\end{abstract}

Keywords: Fas/CD95; HSP70; urothelial cell carcinoma

Correspondence: Heryanto, Department of Pathology, Faculty of Medicine, Universitas Airlangga, Dr. Soetomo Hospital, Surabaya. Email: heryanto.pa013@gmail.com

\section{INTRODUCTION}

Carcinoma of the bladder is the most frequent $(90 \%)$ malignancy found in the urogenital tract (Hall et al 2007). Approximately 336,000 cases are found annually. Carcinoma of the bladder happens $2-5 \mathrm{x}$ more frequent in men compared to women. This is caused by the difference in smoking habit and occupational exposure between them. Multiple risk factors are asssociated with carcinoma of the bladder. External risk factors, such as smoking, work environment, and lifestyle, are associated with carcinogen (Yamana et al 2005).
Most of the bladder carcinoma is in the form of urothelial carcinoma (90\%). This disease has various appearances and varies between non-muscle invasive $(70 \%$ of new cases of urothelial carcinoma of the bladder) and muscle invasive $(30 \%)$. Non-invading lesi-ons recur more frequently, but they generally are not related with mortality, whereas muscular layer-invading lesions are more progressive and related with poor sur-vival (Prasad et al 2011). Staging in urothelial carci-noma is divided into clinical and pathological staging. Clinical staging is based on histological finding, clinical and radiological examination, while pathological stag-ing is based on disease spreading in surgical resection and 
involvement of lymph nodes in the pelvic area (Hall et al 2007).

In the carcinoma of the bladder, uncontrolled proliferation and spreading of abnormal tumor cells can be caused by failure of apoptosis (Bryan et al 2005). Tumor growth is a result of cell proliferation and/or cell survival increase via apoptosis inhibition, besides the gene activity, which is the tumor growth factors; as well as inhibition on genes suppressing tumor growth. In apoptosis, caspase can be activated using two pathways, the intrinsic (mitochondrial) and extrinsic (receptor) pathways (Kumar et al 2010).

In the extrinsic pathway, if one of the activators of Fas receptor caspase pathway, the CD95 receptor, a family of tumor necrosis factor, bonds with its ligand, three molecule will join and FADD (Fas-Associated protein with Death Domain) will be formed, activating procaspase into caspase and mediates the apoptosis process (Kumar et al 2010, Peter et al 2015).

Tumor cells have their own mechanism in response to stress which disrupt protein synthesis. There is a protector known as chaperone. HSP (Heat Shock Protein) is one example of the protector. In mammals, accor-ding to the molecular weight, HSP is divided into HSP90, HSP70, and HSP60. Role of HSP70 is to inhibit caspase activation, making apoptosis unavailable, hence the growth of tumor cells (Zorzi \& Bonvini 2011).

In this study, the examination of HSP70 and CD95 protein expressions in bladder urothelial carcinoma using immunohistochemical staining in various staging of bladder carcinoma was conducted. With the basic mindset that the presence of tumor stimulates the body to protect itself, one of which is via the apoptotic pathway, tumor presence may elevate CD95. Besides, tumor cells also have their self-defense mechanism by secreting HSP70 to prevent apoptosis. So, the higher the staging, the lower the CD95 and the higher the HSP70.

\section{MATERIALS AND METHODS}

This was an analytic observational study using cross sectional approach. Study samples were 37 paraffin blocks of patients with invasive urothelial cell carcinoma in the Laboratory of Anatomic Pathology, Dr. Soetomo Hospital, Surabaya from January 2011-December 2015. Data were taken using random and total sampling and divided into two groups in each histological differentiation grade of urothelial cell carcinoma in the bladder.
Samples were taken from the paraffin blocks of invasive urothelial carcinoma which met the inclusion criteria. The inclusion criteria were as follows: having enough tumor cells to perform immunohistochemistry examination, no history of malignant disease, and no history of radiotherapy and chemotherapy.

Protein expression of Fas/CD95 was examined by immunohistochemistry using antibodies anti Fas/CD95. It was positive if it stained to the nucleus, cell membrane or cytoplasm. It was counted visually with binocular light microscope with magnification of 400 times by two observers. If there was a difference, the average percentage was taken. Then, semiquantitative score based on the percentage of tumor cells which stained positive was made. If tumor cell was stained $0 \%$, the score was 0 . If it was stained $<40 \%$, the score was 1 . If it was stained $40-60 \%$, the score was 2 . If it was stained $>60 \%$, the score was 3 . If it was stained until $100 \%$, the score was 4 (Strater et al 2005, Chatzitolios et al 2009).

Protein expression of HSP70 was examined by immunohistochemistry using antibodies anti HSP70. It was positive if it was stained to the nucleus or cytoplasm. It was counted visually with binocular light microscope with magnification of 400 times by two observers. If there was a difference, the average percentage was taken. Then, a semiquantitative score was based on the percentage of tumor cells which was stained positive. If tumor cell was stained $<5 \%$, the score was 0 . If it was stained $<5-25 \%$, the score was 1 . If it was stained $26-50 \%$, the score was 2 , If it was stained 51$75 \%$, the score was 3 . If it was stained $76-100 \%$, the score was 4 (Tavassol et al 2011)

\section{RESULTS}

Subjects in this study had mean age of $54.95 \pm 13.73$ years old. The youngest was 27 years old and the oldest was 77 years old. According to age, subjects were divided into 3 groups: 0-40 years, 41-60 years, and more than 60 years old. The largest age group of patients with urothelial cell carcinoma was in 41-60 years old group, accounting for $45.9 \%$ of total subject. Paired t-test showed no age difference between low- and high grade urothelial carcinoma groups $(\mathrm{p}=0.309 ;>0.05)$.

According to sex, 16 samples $(80.0 \%)$ of the high differentiation grade group and 15 samples $(88.2 \%)$ of the low differentiation group were men. In this study, measurement of CD95 and HSP70 expressions on each sample group according to percentage of positively stained cells was performed, and Mann-Whitney test gave the result as follows: there was significant corre- 
lation of both CD95 and HSP70 expressions and the low and high grade of urothelial cell carcinoma $(\mathrm{p}<0.05)$.

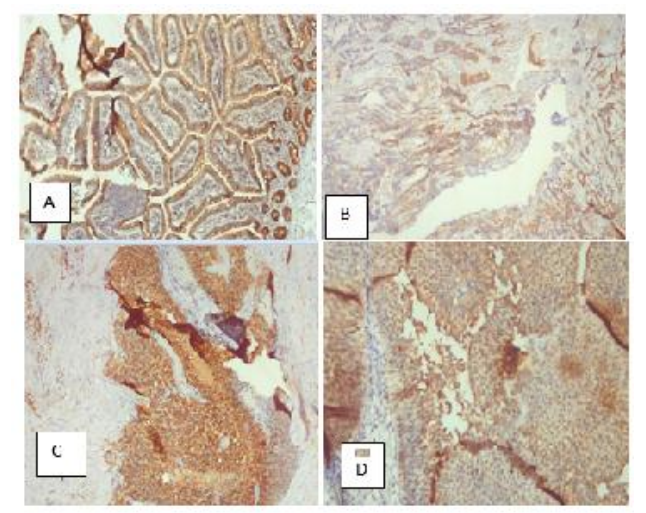

Fig. 1. CD95 expressions and scores. A. Control; B. Score 2 CD95; C. Score 3 CD95; D. Score 4 CD95 (100x magnification).

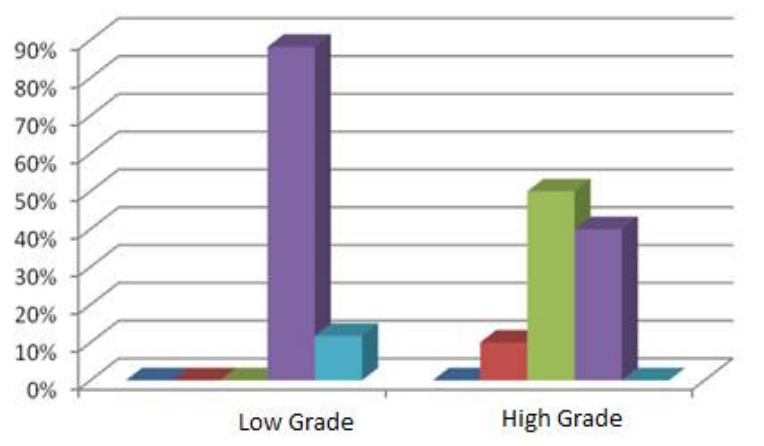

Fig. 2. Distribution of urothelial cell carcinoma differentiation based on CD95 score.

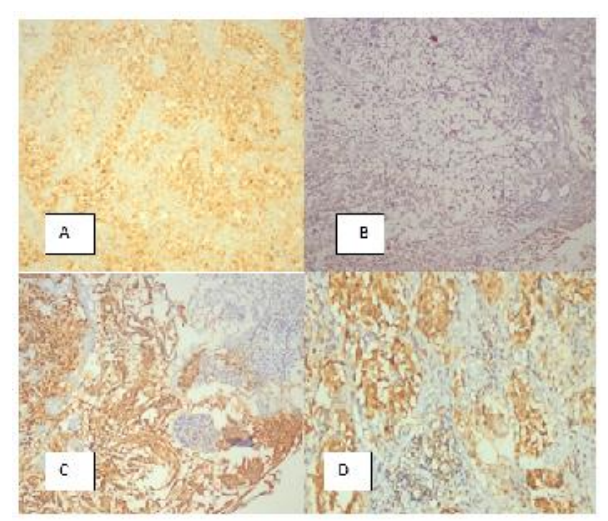

Fig. 3. HSP70 expressions and scores. A. Control; B. Score 2 HSP70; C. Score 3 HSP70; D. Score 4 HSP70 (100x magnification).

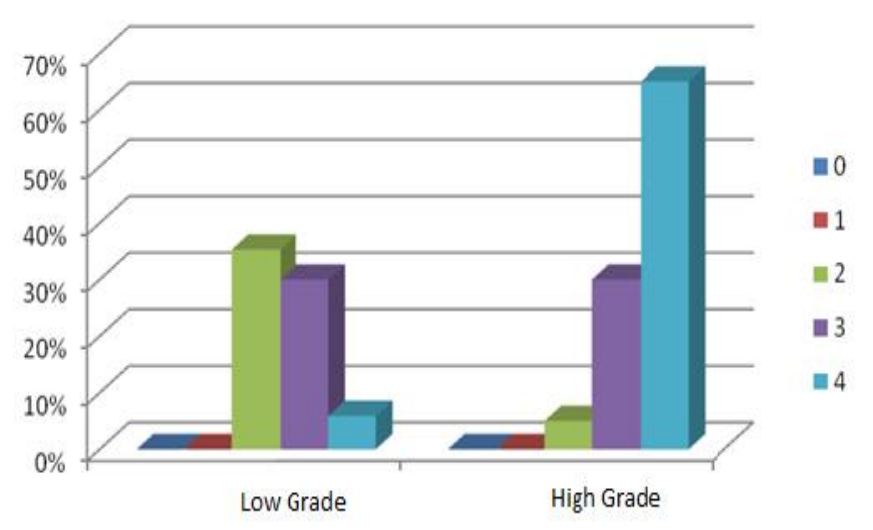

Fig. 4. Distribution of urothelial cell carcinoma differentiation based on HSP70 score.

The correlation between CD95 and HSP70 expressions was analyzed using Spearman correlation test The results were as follows: As for all groups of urothelial cell carcinoma, rs value of -0.164 was obtained ( $>0.33$ ), thus there was no correlation between CD95 and HSP70 expressions.

\section{DISCUSSION}

The data were divided into 3 groups according to age, which were 0-40 years, 41-60 years, and $>60$ years old groups. Urothelial cell carcinoma was most frequently found in the 41-60 years old group (17 cases, 45.9\%) with 9 high grade cases (46\%) and 8 low grade cases $(47.1 \%)$. This result is consistent with the study conducted previously which stated that $80.6 \%$ of urothelial cell carcinoma cases were found in people with more than 50 years of age (Al-Bazzaz 2009).

According to sex, urothelial cell carcinoma was most frequently found in men, 16 cases (80\%) compared to 4 cases in women $(20 \%)$. Whereas, in low grade urothelial cell carcinoma, 15 cases $(88.2 \%)$ were in men. According to Indian Cancer Registry, urothelial cell carcinoma is the ninth most frequent carcinoma, which is $3.9 \%$ of all carcinomas (Kurkure 2001). Men are more likely to have this disease compared to women (3-4:1). A study conducted by Jordan et al (1987) showed that men are more likely to have this disease compared to women. Higher incidence in men compared to women is likely be caused by the difference in smoking habit and occupational substances exposure. 
Table 1. CD95 expression distribution in various differentiation grades of urothelial cell carcinoma

\begin{tabular}{|c|c|c|c|c|c|c|c|c|c|c|c|c|}
\hline \multirow{2}{*}{ Differentiation } & \multicolumn{10}{|c|}{ Fas/CD95 Score } & \multirow{2}{*}{\multicolumn{2}{|c|}{ Total }} \\
\hline & 0 & & 1 & & 2 & & 3 & & 4 & & & \\
\hline Low grade & 0 & $0 \%$ & 0 & $0 \%$ & 0 & $0 \%$ & 15 & $88.23 \%$ & 2 & $11.76 \%$ & 17 & $45.95 \%$ \\
\hline High grade & 0 & $0 \%$ & 2 & $10 \%$ & 10 & $50 \%$ & 8 & $40 \%$ & 0 & $0 \%$ & 20 & $54.05 \%$ \\
\hline Total & 0 & $0 \%$ & 2 & $5.40 \%$ & 10 & $27.03 \%$ & 23 & $62.16 \%$ & 2 & $5.40 \%$ & 37 & $100 \%$ \\
\hline
\end{tabular}

Table 2. HSP70 expression distribution in various differentiation grades of urothelial cell carcinoma

\begin{tabular}{|c|c|c|c|c|c|c|c|c|c|c|c|c|}
\hline \multirow{2}{*}{ Differentiation } & \multicolumn{10}{|c|}{ HSP70 Score } & \multirow{2}{*}{\multicolumn{2}{|c|}{ Total }} \\
\hline & 0 & & 1 & & 2 & & 3 & & 4 & & & \\
\hline Low grade & 0 & $0 \%$ & 0 & $0 \%$ & 6 & $35.2 \%$ & 10 & $58.8 \%$ & 1 & $5.88 \%$ & 17 & $45.9 \%$ \\
\hline High grade & 0 & $0 \%$ & 0 & $0 \%$ & 1 & $5 \%$ & 6 & $30 \%$ & 13 & $65 \%$ & 20 & $54.0 \%$ \\
\hline Total & 0 & $0 \%$ & 0 & $0 \%$ & 7 & $18.9 \%$ & 16 & $43.2 \%$ & 14 & $37.8 \%$ & 37 & $100 \%$ \\
\hline
\end{tabular}

In this study, there was a difference between CD95 expression in high grade urothelial cell carcinoma compared to low grade. In low grade group, there was a tendency of reduced CD95 expression, proven by the highest score which was $2+$ in 10 samples, followed by $3+$ score in 8 samples and no sample with a $4+$ score. Whereas, in low grade urothelial cell carcinoma, a tendency of elevated CD95 expression was seen, as no sample had scores of 0 to $2+$. Fifteen samples with $3+$ score and 2 samples with $4+$ score were found.

In urothelial carcinoma, CD95/Fas was down regulated. Furthermore, Yamana et al (2005) stated that immunoreactivity against CD95/Fas was inversely correlated with the increase of pathological differentiation grade and higher tumor staging. The absence of CD95/Fas results in increasing tumor progressiveness.

Related to the HSP70 in 20 samples of high grade urothelial cell carcinoma, there was a sample with $2+$ score (5\%), 6 samples with $3+$ score $(30 \%)$ and 13 samples with $4+$ score $(65 \%)$. Whereas, in low grade group, there were 6 samples with $2+$ score $(35.29 \%), 10$ samples with $3+$ score $(58.82 \%)$ and a sample with a $4+$ score $(5.88 \%)$. According to latest study about a family member of HSP chaperone family, HSP70 showed correlation with staging and grading in patients with bladder urothelial cell carcinoma. HSP70 protein induces tumor cell growth by inhibiting programmed cell death and/or stabilize lysosome membrane (Garg et al 2010).

In this study, there was no correlation between CD95 and HSP expressions in each group, either in high or low grade carcinoma group. Another study concluded that CD95/Fas that induced the apoptosis pathway did not activate either HSF1 or HSP70. This shows that apoptosis mediated by CD95/Fas does not show a stress factor which raises HSP70, thus the abundance of HSP70 expression in cells undergoing apoptosis is not caused by the induction of CD95/Fas, but caused by stress or underlying trauma.

\section{CONCLUSION}

The role of CD95 and HSP70 expression can be useful as a marker for the diagnosis, especially in determining the grade of differentiation.

\section{REFERENCES}

Al-Bazzaz PH (2009). Stage of urinary bladder cancer at first presentation. Saudi Journal of Kidney Diseases and Transplantation 20, 628-631

Bryan RT, Hussain SA, James ND, Jankowski JA, Wallace DM (2005). Molecular pathways in bladder cancer: part 1. BJU Int 95, 485-490

Chatzitolios A, Venizelos I, Tripsianis G (2010). Prognostic significance of CD95, P53, and BCL2 expression in extranodal non-Hodgkin's lymphoma. Ann Hematol 89, 889-896

Garg M, Kanojia D, Seth A, Kumar R, Gupta A, Surolia A, Suri A (2010). Heat-shock protein 70-2 (HSP70-2) expression in bladder urothelial carcinoma is associated with tumour progression and promotes migration and invasion. European Journal Of Cancer 46, 207215

Hall MC, Chang S, Balbagni G, et al (2007). Guideline for the management of nonmuscle invasive bladder cancer: (stages Ta, T1 and Tis): Update. American Urological Association.

Jordan AM, Weingarten J, Murphy WM (1987). Transitional cell neoplasms of the urinary bladder. Can 
biologic potential be predicted from histologic grading? Cancer 60, 2766-74

Kumar V, Abbas AK, Fausto N (2005) Cellular adaptations, cell injury, and cell death. In: Robbins and Cotran Pathologic Basis of Disease. 8th ed. Philadelphia, Elsevier, pp 25-32

Peter ME, Hadji A, Murmann AE (2015) The role of CD95 and CD95 ligand in cancer. Macmillan Publishers Limited All rights reserved 1350-9047/15. Downloaded from www.nature.com/cdd

Prasad SM, DeCastro J, Steinberg GD (2011) Urothelial carcinoma of the bladder: definition, treatment and future efforts. Nat Rev Urology, 1-12

Strater J, Hinz U, Hasel C (2005) Impaired CD95 expression predisposes for recurrence in curatively resected colon carcinoma: clinical evidence for immu- noselection and CD95L mediated control of minimal residual disease. Gut 54, 661-665

Tavassol F, Starke OF, Kokemuller H (2011). Prognostic significance of heat shock protein 70 (HSP70) in patients with oral cancer. Head \& Neck Oncology 3, 10

Yamana K, Bilim V, Hara N (2005). Prognostic impact of FAS/CD95/APO-1 in urothelial cancers: decreased expression of Fas is associated with disease progression. British Journal of Cancer 93, 544 - 551

Zorzi E, Bonvini P (2011) Inducible Hsp70 in the regulation of cancer cell survival: analysis of chaperone induction, expression and activity. Cancers 3, 3921-3956. doi:10.3390/cancers3043921. www.mdpi. com/journal/cancers 